telangiectasia in a local community in the northern part of Japan. Hum Mutat 2002;19:140-148.

3. Canzonieri C, Centenara L, Ornati F, Pagella F, Matti E, Alvisi C, Danesino C, Perego $M$, Olivieri C. Endoscopic evaluation of gastrointestinal tract in patients with hereditary hemorrhagic telangiectasia and correlation with their genotypes. Genet Med 2014;16:3-10.

4. Grève E, Moussata D, Gaudin JL, Lapalus MG, Giraud S, Dupuis-Girod S, Calender A, Plauchu H, Saurin JC. High diagnostic and clinical impact of small-bowel capsule endoscopy in patients with hereditary hemorrhagic telangiectasia with overt digestive bleeding and/or severe anemia. Gastrointest Endosc 2010;71:760-767.

5. Chamberlain SM, Patel J, Carter Balart J, Gossage JR Jr, Sridhar S. Evaluation of patients with hereditary hemorrhagic telangiectasia with video capsule endoscopy: a single-center prospective study. Endoscopy 2007;39:516-520.

6. Ingrosso $M$, Sabbà $C$, Pisani $A$, Principi $M$, Gallitelli $M$, Cirulli $A$, Francavilla A. Evidence of small-bowel involvement in hereditary hemorrhagic telangiectasia: a capsule endoscopic study. Endoscopy 2004;36:1074-1079.
7. Holleran G, Hall B, Breslin N, McNamara D. Long-acting somatostatinanalogues provide significant beneficial effect in patients with refractory small bowel angioectasia: results from a proof of concept open label monocentre trial. United European Gastroenterol J 2016;4:70-76.

8. Sauer H, Gunther J, Hescheler J, Wartenberg M. Thalidomide inhibits angiogenesis in embryoid bodies by the generation of hydroxyl radicals. Am J Pathol 2000;156:151-158.

9. Izquierdo Navarro Mdel C, Hernando Verdugo M, Cardaba Garcia E, Sanchez Sanchez MT. Therapeutic failure with thalidomide in patients with recurrent intestinal bleeding due to angiodysplasias. Farm Hosp 2016;40:230-232.

10. Palumbo A, Rajkumar SV, Dimopoulos MA, Richardson PG, San Miguel J, Barlogie B, Harousseau J, Zonder JA, Cavo M, Zangari M, Attal M, Belch A, Knop S, Joshua D, Sezer O, Ludwig H, Vesole D, Bladé J, Kyle R, Westin J, Weber D, Bringhen S, Niesvizky R, Waage A, von Lilienfeld-Toal M, Lonial S, Morgan GJ, Orlowski RZ, Shimizu K, Anderson KC, Boccadoro M, Durie BG, Sonneveld P, Hussein MA; International Myeloma Working Group. Prevention of thalidomide- and lenalidomide-associated thrombosis in myeloma. Leukemia 2008;22:414-423.

\title{
Interleukin-2-330T/G and Interleukin-10-1082A/G Genetic Polymorphisms and B-Cell Non-Hodgkin Lymphoma
}

\author{
İnterlökin-2-330T/G ve İnterlökin-10-1082A/G Genetik Polimorfizmi ve B-Hücreli Non- \\ Hodgkin Lenfoma
}

\author{
(D) Beuy Joob1, (D) Viroj Wiwanitkit² \\ 1Sanitation 1 Medical Academic Center, Bangkok, Thailand \\ ${ }^{2}$ Honorary professor, Dr DY Patil University, Pune, India
}

To the Editor,

We read the publication "Association of Interleukin-2-330T/G and Interleukin-10-1082A/G Genetic Polymorphisms with B-Cell Non-Hodgkin Lymphoma (B-NHL) in a Cohort of Egyptians" with great interest [1]. Abdel Rahman et al. [1] concluded that "The present study highlights the possible involvement of the [interleukin (IL)] IL-2-330T/G genetic polymorphism in the susceptibility to [B-NHL] B-NHL in Egypt, especially indolent subtypes. Moreover, IL-10-1082A/G is not a molecular susceptibility marker for B-NHL in Egyptians" [1]. In fact, the role of polymorphism of IL is widely mentioned in relationship to NHL susceptibility [2]. We agree with the observation of Abdel Rahman et al. [1]. The differences of the effects of IL2-330T/G and IL-10-1082A/G can be explained by molecular quantum calculations of molecular weight changes. This is the same phenomenon as seen in other polymorphisms and it can affect the clinical appearance of many medical disorders, such as the effect of CTLA-4 A49G polymorphism on autoimmune blood disease [3]. For IL-2-330T/G and IL-10-1082A/G, the change of molecular weight is equal to -107.07 and +16 per molecule, respectively. This means that a molecule with IL$2-330 T / G$ requires more molecular mass and a molecule with IL-10-1082A/G requires less molecular mass to complete a biological process compared to a naïve molecule.

Keywords: Interleukin, Lymphoma, Polymorphism

Anahtar Sözcükler: İnterlökin, Lenfoma, Polimorfizm

Conflict of Interest: The authors of this paper have no conflicts of interest, including specific financial interests, relationships, 
and/or affiliations relevant to the subject matter or materials included.

\section{References}

1. Abdel Rahman HA, Khorshied MM1, Reda Khorshid OM2, Mourad HM. Association of interleukin-2-330T/G and interleukin-10-1082A/G genetic polymorphisms with B-cell non-Hodgkin lymphoma in a cohort of Egyptians. Turk J Hematol 2018;35:99-108.

2. Li G, Li D. Relationship between IL-10 gene polymorphisms and the risk of non-Hodgkin Iymphoma: a meta-analysis. Hum Immunol 2016;77:418-425.

3. Wiwanitkit V. CTLA-4 A49G polymorphism and autoimmune blood disease: a comment. Turk J Hematol 2011;28:247.

\title{
On Being a "Physician Patient" with His Own Experimental Therapeutic Drug
}

\author{
Deneysel Tedavi Edici llaç ile "Doktor Hasta" Birlikteliği Üzerine
}

(D) Rafiye Çiftçiler, (D) ibrahim C. Haznedaroğlu

Hacettepe University Faculty of Medicine, Department of Hematology, Ankara, Turkey

\section{To the Editor,}

We have read with great interest the paper by Patıroğlu et al. [1] on the mucosal healing effects of Ankaferd BloodStopper (ABS), recently published in this journal. They suggested that ABS could be effective for the management of chemotherapyinduced mucositis. We would like to share our own experience with $A B S$ on the burn-induced skin wounds of a patient.

The patient herein is a physician and the senior author of this paper (i.C.H.). He is also the mentor of the first author (R.Ç.). The experimental therapeutic drug is ABS, which was developed as a medicine with numerous clinical studies (https://www.ncbi.nlm. nih.gov/m/pubmed/?term=ankaferd), mostly authored by i.C.H. himself. ABS is the first topical hemostatic agent acting on red blood cells and fibrinogen gamma interactions to be tested in clinical trials [2]. ABS is a drug officially approved for the management of clinical hemorrhages in Turkey [3]. However, ABS has never been used in humans for the therapy of burns until I.C.H. had his left forearm severely burned by a boiling tea kettle. In his physical examination, the burnt areas had acutely developed heavy erythematous lesions, which then complicated into several bullous lesions.

At the time of the burn accident, ABS for burn wound management had only been demonstrated in rats $[4,5]$. The burns were induced in Wistar albino rats by Kaya et al. [4] they showed that ABS decreases the inflammation and wound diameters and increases the wound contraction and tissue fibrosis in rats with burn injuries. The results of another rat study demonstrated that $A B S$ has a positive effect on second-degree thermal burn healing [6].

The emergency state of the severe burn lesions and the availability of $A B S$ at the time of the accident enabled us to apply it topically to the burn lesions of I.C.H. The burn lesions were clearly regressed and wound healing occurred with no complications upon the usage of ABS in our physician patient (Figure 1).

In the history of medical science, there are many inventors that applied their own therapeutic tools for the management of their own diseases, such as Dr. Barry J. Marshall. He drank Helicobacter pylori bacteria himself and developed stomach ulcers within a few days. He later successfully treated himself with antibiotics and went on to win the Nobel Prize [7].

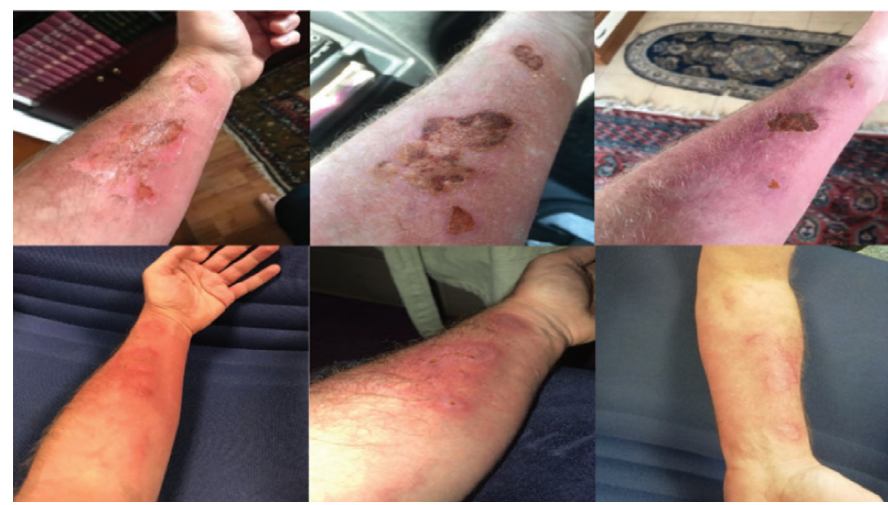

Figure 1. The senior author's burn wounds before and after treatment with Ankaferd BloodStopper. 